\title{
OPINI PESERTA TERHADAP TRANSPARANSI PENERIMAAN CPNS MELALUI METODE COMPUTER ASSISTED TEST (CAT)
}

\author{
Sulaiman $^{1)}$ \& Dody Radiansah ${ }^{2)}$ \\ ${ }^{1}$ Administrasi Bisnis, Politeknik Negeri Pontianak \\ email: imansulaiman137@yahoo.co.id \\ 2 Teknologi Pertanian, Politeknik Negeri Pontianak \\ email: dodyradiansah10@gmail.com
}

\begin{abstract}
This study aims to determine the opinion of participants on the level of transparency of the selection of CPNS acceptance through the CAT method at the Bengkayang Regency Regional Personnel Agency. The research location is in Bengkayang Regency. This type of research is a survey method with a quantitative approach. Data were analyzed by descriptive statistics. Descriptive statistics describe participants' opinions on the level of transparency in the selection of candidates for civil servants through the CAT method. The population in this study were all participants who took part in the selection of CPNS acceptance at the Bengkayang Regency Regional Personnel Agency in 2020. Sampling was carried out by stratified random sampling with a sample of 41 people. The results showed that the participants' opinions on the level of transparency of the selection of CPNS admissions through the CAT method for each dimension on average were in the good and very good categories; so this shows that the opinion of participants on the level of transparency of the selection of CPNS acceptance through the CAT method at the Bengkayang Regency Regional Personnel Agency is very positive.
\end{abstract}

Keywords: Transparancy, CPNS acceptance, Computer Assisted Test

\section{PENDAHULUAN}

Selama ini proses rekruitmen CPNS yang dilaksanakan oleh pemerintah dipandang belum mampu mendapatkan kompetensi yang sesuai dengan kebutuhan organisasi. Proses dan prosedur rekrutmen banyak dinilai publik cenderung diwarnai oleh praktik-praktik spoil system, yang masih cenderung mengedepankan praktek korupsi, kolusi, dan nepotisme (KKN), sehingga mengakibatkan rendahnya kualitas PNS. Kualitas PNS akan sangat ditentukan oleh sistem rekruitmen yang merupakan bagian dari pada proses aktivitas untuk mencari dan menemukan PNS yang memiliki motivasi, kemampuan, keahlian, dan pengetahuan yang diperlukan dalam melaksanakan tugas jabatannya.

Proses penerimaan seleksi Calon Pegawai Negeri Sipil di Indonesia dinilai masih sangat buruk dan menimbulkan kerawanan terjadinya korupsi, kolusi dan nepotisme. Proses pendaftaran yang rumit ditambah seleksi yang konvensional menunjukkan sejak dini Calon Pegawai Negeri Sipil telah dikondisikan dalam sebuah situasi kerja yang birokratis, "superficial", serta tidak berbasis pada keahlian atau kompetensi secara menyeluruh.

Indikasi penyimpangan hampir setiap tahun terjadi pada penerimaan Calon Pegawai Negeri Sipil yang melibatkan oknum pejabat Kementerian Pemberdayaan Aparatur Negara dan 
Reformasi Birokrasi, mafia, perantara, oknum bupati/walikota hingga oknum panitia seleksi. Pada tahun 2021 ada beberapa modul kecurangan yaitu menggunakan remote access. Modul ini memungkinkan seseorang yang berada di lokasi berbeda mengakses komputer yang digunakan peserta saat tes berlangsung. Orang tersebut kemudian bisa membantu peserta untuk menyelesaikan soal-soal ujian. Informasi terkait kecurangan ini terjadi dalam seleksi Calon Aparatur Sipil Negara (CASN) di Buol, Sulawesi Tengah (https://finance.detik.com ).

Buruknya proses penerimaan dan seleksi Pegawai Negeri Sipil (PNS) di Indonesia juga dibuktikan dengan bertambahnya jumlah kabupaten/kota yang bermasalah dalam seleksi Calon Pegawai Negeri Sipil tahun 2021. Jika sebelumnya hanya 202 orang yang dilaporkan ada kecurangan selama seleksi, kini menjadi 225 orang.

Data terkini dari Badan Kepegawaian Negara (BKN) menyebutkan ada 225 kecurangan tes CPNS 2021 yaitu 202 orang di Makasar dan 23 orang di Lampung. BKN dan segenap pelaksana seleksi CASN akan melakukan inovasi untuk mencegah kecurangan lagi. Akan diberlakukan sistem Artificial Intelligence (AI) untuk mendeteksi potensi kecurangan peserta selama proses berlangsung. Mereka juga akan melakukan penguatan sistem seperti menggunakan platform yang wajib diterapkan dalam pelaksanaan tes SKB, misalnya menggunakan Linux. (https://www.tribunnews.com).

Kecurangan yang terjadi tidak hanya karena oknum pejabat yang bersangkutan, tapi juga karena sistem manual atau yang disebut dengan metode konvensional. Sistem manual dikenal dengan sistem yang dilakukan dengan LJK terpusat. Sistem perekrutan dengan metode konvensional membuat perekrutan CPNS rawan kecurangan.
Sistem perekrutan di atas, juga mengakibatkan proses rekrutmen CPNS rawan penyelewengan, hal ini sebagaimana dilansir Malang Corruption Watch (MCW) menyebutkan sebanyak 10 titik kerawanan penyelewengan proses rekruitmen CPNS. Menurut Koordinator Divisi Advokasi MCW, Zainuddin penyelewengan tersebut melibatkan pejabat pemerintah, panitia seleksi, politisi, dan lembaga swadaya masyarakat (LSM). Termasuk seleksi jalur honorer kategori 2 dan jalur umum. Kesepuluh titik rawan itu antara lain kebocoran soal ujian, perjokian, suap, penyelundupan data dan saling titip pejabat lintas daerah." (https://nasional.tempo.co/read/510369/m cw-catat-10-titik-rawan-kecuranganseleksi-cpns).

Deputi Kepala Badan Pengawasan Keuangan dan Pembangunan (BPKP) mengatakan, seleksi CPNS khususnya yang menggunakan sistem lembar jawaban komputer (LJK) rawan korupsi, kolusi dan nepotisme, dan berbagai penyimpangan lain. Untuk mencegah hal itu, seluruh proses pelaksanaannya harus transparan. Transparansi menjadi prinsip utama mencegah KKN. (www.menpan.go.id)

Guna mengatasi lemahnya sistem konvensional yang sarat akan kecurangan, maka instansi pemerintah meningkatkan kualitas Pegawai dalam hal proses seleksi penerimaan Calon Pegawai Negeri Sipil melalui penggunaan alat bantu komputer atau disebut Computer Assisted Test (CAT).

Menurut Simamora (2016:170), yang dimaksud dengan rekrutmen (recruitment) serangkaian aktivitas untuk mencari dan memikat pelamar kerja dengan motivasi, kemampuan, keahlian, dan pengetahuan yang diperlukan guna menutupi kekurangam perencanaan kepegawaian. Pemerintah meningkatkan kualitas pegawai dalam hal proses seleksi penerimaan CPNS melalui penggunaan 
alat bantu komputer atau disebut Computer Assisted Test (CAT).

Menurut Pusat Pengembangan Sistem Rekruitmen PNS BKN (2010), sistem rekruitmen model CAT ini menggunakan pendekatan computeraise, artinya sistem seleksi CPNS akan menjalankan tes seleksi dengan menggunakan komputer secara langsung dan hasil penilaian melalui grade-nya bisa dilihat pada saat itu juga.

Menggunakan

menjadikan sistem CAT sebagai terobosan teknologi komunikasi dan informasi (TIK) dalam bidang reformasi Birokrasi. Penerapan TIK pada organisasi pemerintah tentunya memiliki tujuan yang berbeda. Adapun yang menjadi tujuan dari adanya teknologi informasi menurut Sutarman (2019), yaitu untuk memecahkan masalah, membuka kreativitas, dan meningkatkan efektivitas dan efesiensi dalam melakukan pekerjaan.

Tujuan CAT adalah meningkatkan transparansi, obyektivitas, akuntabilitas dan efisiensi. Menurut Sinambela (2016), secara teoritis tujuan pelayanan publik pada dasarnya adalah memuaskan masyarakat. Untuk mencapai kepuasan itu dituntut kualitas pelayanan prima yang salah satunya tercermin dari transparansi. Dengan memiliki akses terhadap berbagai jenis informasi itu, maka masyarakat dan stakeholders dapat menilai sejauhmana keberpihakan pemerintah terhadap kepentingan mereka dan mengambil sikap yang tepat dalam merespons kebijakan yang diambil oleh pemerintah tersebut. Dengan konsep transparansi informasi yang diusung oleh seleksi penerimaan CPNS melalui metode CAT diharapkan bisa menciptakan opini yang positif terhadap pemerintah dalam hal penyelenggaraan seleksi penerimaan CPNS.

Penerapan Computer Assisted Test (CAT) pertama kali di Indonesia pada tahun 2010 yang diselenggarakan oleh BKN Pusat. Adapun untuk penerapan di daerah, BKN Pusat berkoordinasi dengan Kantor Regional BKN. Pemerintah Provinsi Sulawesi Barat melalui Badan Kepegawaian Daerah menerapkan CAT dalam rekrutmen CPNS untuk pertama kalinya dilaksanakan pada tahun 2013 bertempat di Kantor Regional IV BKN Makassar. BKD provinsi Sulawesi Barat adalah instansi pemerintah daerah di Indonesia Timur yang pertama melaksanakan seleksi penerimaan CPNS berbasis CAT.

Berdasarkan latar belakang tersebut maka penelitian ini bertujuan untuk mengetahui opini peserta terhadap tingkat transparansi seleksi penerimaan CPNS melalui metode Computer Assisted Test (CAT) pada Badan Kepegawaian Daerah Kabupaten Bengkayang.

\section{KAJIAN LITERATUR}

\section{Teknologi Komunikasi dan Informasi}

Menggunakan computerize menjadikan sistem CAT sebagai terobosan teknologi komunikasi dan informasi (TIK) dalam bidang reformasi Birokrasi. Teknologi komunikasi (TK) menurut Rogers (1986), adalah peralatan perangkat keras (hardware) dalam sebuah struktur organisasi yang mengandung nilai-nilai sosial, yang memungkinkan setiap individu mengumpulkan, memproses, dan saling tukar menukar informasi dengan individu-individu lainnya. Sedangkan menurut Ishak (2018), teknologi informasi adalah hasil rekayasa manusia terhadap proses penyampaian informasi dari pengirim ke penerima sehingga pengiriman informasi akan lebih cepat, lebih luas sebarannya, dan lebih lama penyimpanannya.

Penerapan TIK pada organisasi pemerintah tentunya memiliki tujuan yang berbeda. Adapun yang menjadi tujuan dari adanya teknologi informasi menurut 
Sutarman (2019), yaitu untuk memecahkan masalah, membuka kreativitas, dan meningkatkan efektivitas dan efesiensi dalam melakukan pekerjaan. Menurut Jogiyanto (2013), mengungkapkan bahwa teknologi informasi mempunyai peran utama di dalam organisasi yaitu untuk meningkatkan: efisiensi; efektivitas; komunikasi; dan kompetitif.

Salah satu teori komunikasi klasik yang sangat mempengaruhi teori-teori komunikasi selanjutnya adalah teori informasi atau teori matematis. Teori ini merupakan bentuk penjabaran dari karya Claude Shannon dan Waren (1949), Mathematical Theory of Communication. Teori Teori ini melihat komunikasi sebagai fenomena mekanistis, matematis, dan informatif. Komunikasi sebagai transmisi pesan dan bagaimana transmitter menggunakan saluran dan media komunikasi. Ini merupakan salah satu contoh gamblang dari mazhab proses yang mana melihat kode sebagai sarana untuk mengonstruksi pesan dan menerjemahkannya (encoding dan decoding).

Titik perhatiannya terletak pada akurasi dan efisiensi proses. Proses yang dimaksud adalah komunikasi seorang pribadi yang mempengaruhi tingkah laku atau state of mind pribadi yang lain. Jika efek yang ditimbulkan tidak sesuai dengan apa yang diharapkan, maka mahzab ini cenderung berbicara tentang kegagalan komunikasi. Ia melihat ke tahap-tahap dalam komunikasi tersebut untuk mengetahui dimana letak kegagalannya. Selain itu mahzab proses juga cenderung mempergunakan ilmu-ilmu sosial, terutama psikologi dan sosiologi, dan cenderung memusatkan diriya pada tindakan komunikasi.

Teori informasi Shannon menganggap bahwa informasi dapat dihitung jumlahnya, dan bahwa informasi bersumber atau bermula dari suatu kejadian. Jumlah informasi yang dapat dikaitkan, atau dihasilkan oleh, sebuah keadaan atau kejadian merupakan tingkat pengurangan (reduksi) ketidakpastian, atau pilihan kemungkinan, yang dapat muncul dari keadaan atau kejadian tersebut. Dengan kata yang lebih sederhana, teori ini berasumsi bahwa kita memperoleh informasi jika kita memperoleh kepastian tentang suatu kejadian atau suatu hal tertentu. (Agnes, 2013: 76).

\section{Opini}

Cangara (2015:10) mengemukakan bahwa opini ialah tindakan mengungkapkan apa yang dipercayai, dinilai, dan diharapkan seseorang dari objek-objek dan situasi tertentu. Dengan demikian publik adalah pendapat khalayak terhadap sesuatu objek atau situasi tertentu yang dipercayai, dinilai baik dan benar atau diharapkan. Tindakan tersebut bisa merupakan pemberian suara, pernyataan verbal, dokumen tertulis atau bahkan diam; singkatnya apapun yang bermakna adalah ungkapan opini.

Proses pembentukan opini publik dalam setiap kasus berbeda-beda, ada yang cepat, lambat, bahkan ditangguhkan. Faktor-faktor tertentu membatasi dan mempengaruhi sejumlah fakta, pengalaman dan penilaian yang menjadi dasar pembentukan opini. Ada kemungkinan terjadi sejumlah kombinasi antar faktor yang menguatkan kesamaan opini, tetapi ada sejumlah faktor lain yang menguatkan keanekaragaman opini. Seperti terlihat dalam gambar dibawah tentang proses terbentuknya opini seseorang (Cangara, 2014:135).

\section{Transparansi}

Transparansi merupakan prinsip yang menjamin akses atau kebebasan bagi setiap orang untuk memperoleh informasi tentang penyelenggaraan pemerintahan, yakni informasi tentang kebijakan, proses 
pembuatan dan pelaksanaannya, serta hasil-hasil yang dicapai (Krina, 2013). Menurut Kim (2017), adapun unsur-unsur transparansi meliputi: kejelasan (clarity) dalam arti mudah dipahami/dimengerti oleh masyarakat, aksesibilitas (accessibility) dalam arti adanya pertukaran informasi dua arah, integrasi (integration) dalam arti dapat menjelaskan dan memberikan informasi tambahan yang dibutuhkan masyarakat, serta rasional (rationality) dalam arti adanya proses yang konsisten, terstandarisasi, formal, dan dapat diupgrade. Transparansi dalam konteks penyelenggaraan pelayanan publik adalah terbuka, mudah, dan dapat diakses oleh semua pihak yang membutuhkan serta disediakan secara memadai dan mudah dimengerti (Ratminto dan Winarsih, 2015).

Konsep transparansi menunjuk pada suatu keadaan dimana segala aspek dari proses penyelenggaraan pelayanan bersifat terbuka dan dapat diketahui dengan mudah oleh para pengguna dengan stakeholders yang membutuhkan. Jika segala aspek proses penyelenggaraan pelayanan seperti persyaratan, biaya dan waktu yang diperlukan, cara pelayanan, serta hak dan kewajiban penyelenggara dan pengguna layanan dipublikasikan secara terbuka sehingga mudah diakses dan dipahami oleh publik, maka praktek penyelenggaraan pelayanan itu dapat dinilai memiliki transparansi yang tinggi. Sebaliknya, kalau sebagaian atau semua aspek dari proses penyelenggara pelayanan itu tertutup dan informasinya sulit diperoleh oleh para pengguna dan stakeholders lainnya, maka penyelenggaraan pelayanan itu tidak memenuhi kaidah transparansi.

Dari pengertian transparansi diatas maka transparansi penerimaan CPNS melalui metode CAT adalah bahwa segala informasi yang ada pada seleksi ini harus memenuhi unsur keterbukaan informasi, ketersedian informasi dan mudah dimengerti.

Berdasarkan latar belakang masalah yang telah dijelaskan, maka permasalahan adalah Bagaimana opini peserta terhadap tingkat transparansi CPNS melalui sistem Computer Assisted Test (CAT) di Badan Kepegawaian Daerah (BKD) Kabupaten Bengkayang?

\section{METODE PENELITIAN}

Penelitian ini dilakukan di Kabupaten Bengkayang. Dimana Kabupaten Bengkayang adalah instansi pemerintah daerah yang melaksanakan seleksi penerimaan CPNS berbasis Computer Assisted Test sejak tahun 2015. Pelaksanaannya dilakukan oleh Badan Kepegawaian Daerah Kabupaten Bengkayang.

Penelitian ini adalah penelitian survei. Survei adalah metode riset dengan menggunakan kuisioner sebagai instrumen pengumpulan datanya (Kriyantono, 2012). Metode penelitian menggunakan pendekatan kuantitatif karena pendekatan kuantitatif dapat menghasilkan data yang akurat setelah penghitungan yang tepat. Pendekatan kuantitatif merupakan salah satu pendekatan dalam penelitian yang lebih ditekankan pada data yang dapat dihitung untuk menghasilkan penafsiran kuantitatif yang kokoh. Penelitian kuantitatif pun sifatnya adalah objektif, sehingga kita bisa melihat langsung sebuah keadaan.

\section{Populasi dan Sampel}

Populasi dalam penelitian ini adalah semua peserta baik yang lulus maupun tidak lulus yang mengikuti seleksi penerimaan CPNS melalui metode CAT pada Badan Kepegawaian Daerah Kabupaten Bengkayang pada tahun 2020 yaitu sebesar 4056 peserta. Besaran sampel ditentukan menggunakan rumus Slovin untuk populasi yang diketahui 
jumlahnya (Kriyantono, 2012) yaitu $\mathbf{n}=\mathbf{N} / \mathbf{1}+\mathbf{N e}^{\mathbf{2}}$, dimana $\mathbf{n}$ adalah jumlah sampel, $\mathbf{N}$ adalah ukuran populasi dan $\mathbf{e}$ adalah kelonggaran ketidaktelitian karena kesalahan pengambilan sampel yang ditolerir sebesar $10 \%$, sehingga ukuran sampel yang diperoleh adalah 41 orang.

Mengingat populasi dalam kelompok tersebut terdiri dari peserta dalam formasi yang berbeda, yaitu tenaga guru, kesehatan, teknis maka agar sampel yang diambil mewakili setiap formasi maka teknik penarikan sampel yang digunakan yaitu teknik proporsional stratified random sampling untuk setiap formasi pada kedua kelompok peserta.

\section{Teknik Pengumpulan Data}

Data yang digunakan adalah data primer dan data sekunder. Data primer adalah data yang diperoleh melalui penelitian di lapangan secara langsung melalui informan dengan menggunakan kuisioner atau angket (Sugiyono, 2015). Sedangkan data sekunder diperoleh dari informasi atau data yang dikumpulkan dari Badan Kepegawaian Daerah Kabupaten Bengkayang.

Kuisioner penelitian ini menggunakan skala Likert 5 (interval 5). Adapun jumlah pertanyaan yang diajukan dalam kuesioner adalah 39 pernyataan yang bisa dilihat pada tebel dibawah ini.

Tabel 1. Kisi-Kisi Instrumen untuk Mengkur Tingkat Transparansi Seleksi CPNS melalui Opini peserta.

\begin{tabular}{|c|c|c|}
\hline $\begin{array}{c}\text { Variabel } \\
\text { Transparansi }\end{array}$ & Indikator & $\begin{array}{c}\text { Juml } \\
\text {-ah } \\
\text { Bu- } \\
\text { tir }\end{array}$ \\
\hline $\begin{array}{l}\text { a. Keterbukaan } \\
\text { informasi }\end{array}$ & $\begin{array}{l}\text { 1. Pendaftaran } \\
\text { 2. Prosedur/tata cara } \\
\text { 3. Persyaratan } \\
\text { 4. Biaya } \\
\text { 5. Formasi yang } \\
\text { dilamar } \\
\text { 6. Waktu dan lokasi } \\
\text { 7. Kuota formasi } \\
\text { 8. Rencana } \\
\text { penempatan } \\
\text { 9. Ter CAT }\end{array}$ & $\begin{array}{l}2 \\
1 \\
2 \\
1 \\
1 \\
1 \\
1 \\
1 \\
1 \\
1\end{array}$ \\
\hline
\end{tabular}

\begin{tabular}{|c|c|c|}
\hline & $\begin{array}{l}\text { 10. Pengumuman } \\
\text { skoring } \\
\text { 11. Pengumuman } \\
\text { kelulusan }\end{array}$ & 2 \\
\hline $\begin{array}{l}\text { b. Ketersediaan } \\
\text { informasi }\end{array}$ & $\begin{array}{ll}\text { 1. Sumber informasi } \\
\text { 2. Waktu } \\
\text { ketersediaan } \\
\text { 3. Kemudahan akses } \\
\text { 4. Layanan } \\
\text { pengaduan } \\
\text { 5. Adanya solusi } \\
\text { 6. Waktu dan lokasi } \\
\text { 7. Tutorial tes CAT } \\
\text { 8. Informasi hasil } \\
\text { skoring } \\
\text { 9. Informasi } \\
\text { kelulusan }\end{array}$ & $\begin{array}{l}1 \\
1 \\
1 \\
1\end{array}$ \\
\hline $\begin{array}{l}\text { c. Mudah } \\
\text { dimengerti/di } \\
\text {-pahami }\end{array}$ & $\begin{array}{l}\text { 1. Pengumuman } \\
\text { pendaftaran } \\
\text { 2. Persyaratan } \\
\text { pendaftaran } \\
\text { 3. Tata cara } \\
\text { pendaftaran } \\
\text { 4. Tampilan website } \\
\text { 5. Tutorial tes CAT } \\
\text { 6. Soal tes } \\
\text { 7. Instruksi panitia } \\
\text { tes } \\
\text { 8. Tampilan tes CAT } \\
\text { 9. Pengumuman } \\
\text { kelulusan } \\
\text { 10. Pengumuman } \\
\text { skoring }\end{array}$ & $\begin{array}{l}1 \\
1 \\
1 \\
1\end{array}$ \\
\hline
\end{tabular}

\section{Analisis Data}

Pada penelitian ini metode yang digunakan dalam menganalisis data adalah statistik deskriptif. Statistik deskriptif menggambarkan opini peserta terhadap tingkat transparansi seleksi penerimaan calon pegawai negeri sipil melalui metode CAT.

Opini peserta diukur dari jawaban responden akan kuisioner. Data yang telah dikumpulkan dianalisis melalui statistik deskriptif yang berupa tabel frekuensi dari masing-masing varibel dengan lima kriteria penilaian. Lima kriteria penilaian ini terdiri atas 5 tingkatan dari sangat baik/jelas memadai sampai sangat tidak baik/jelas/memadai dimana jumlah skor tergantung dari jumlah responden dan banyaknya pertanyaan. Dalam perhitungan pengolahan data, peneliti 
mempergunakan alat bantu yang berupa aplikasi komputer yaitu SPSS for windows 24 .

\section{HASIL}

Karaktersitik responden merupakan gambaran dari keberadaan responden yang terlibat dalam penelitian yaitu berdasarkan pendidikan, usia, dan jenis kelamin. Dari seluruh peserta yang menjadi sampel yang berjumlah 41 orang yang diberikan kuisioner, semuanya mengisi dan mengembalikan kuisioner yang dibagikan.

Karakteristik responden penelitian ini yakni sebanyak 10 (24\%) responden berpendidikan diploma tiga dan lebihnya yakni $31(76 \%)$ sarjana. Mayoritas jenis kelamin responden adalah wanita yakni 28 (68\%) dan laki-laki sebesar 13 (32\%).

\section{Deskripsi Opini Peserta terhadap transparansi seleksi penerimaan CPNS melalui metode CAT}

Ada tiga dimensi yang menjadi indikator transparansi yaitu : keterbukaan informasi, ketersediaan informasi dan mudah dimengerti. Pada tabel 2 memperlihatkan hasil analisis deskriptif opni peserta terhadap transparansi seleksi penerimaan CPNS melalui metode CAT dihubungkan dengan indeks kepuasan masyarakat terhadap unit instansi pemerintah daerah sesuai dengan KEP/25/M/PAN/2/2004.

Tabel 2. Hasil Analisis Deskriptif Opini Peserta

\begin{tabular}{|r|l|r|r|c|}
\hline No & $\begin{array}{c}\text { Indikator } \\
\text { Transparansi }\end{array}$ & Mean & $\begin{array}{c}\text { Persentasi } \\
\text { Mean }\end{array}$ & $\begin{array}{c}\text { Kategori } \\
\text { Penilaian }\end{array}$ \\
\hline 1. & Keterbukaan Informasi & 58,6 & 84,1 & Sangat Baik \\
2. & Ketersediaan Informasi & 51,02 & 78,5 & Baik \\
3. & Mudah dimengerti & 50,8 & 84,7 & Sangat Baik \\
\hline
\end{tabular}

Sumber : Data Primer diolah, 2020
Tabel 2 menunjukkan bahwa rata-rata opini peserta terhadap semua dimensi transparansi berada pada kategori baik, namun peserta beropini sangat baik pada dimensi keterbukaan informasi dan mudah dimengerti.

\section{PEMBAHASAN}

\section{Analisis Opini peserta terhadap seleksi penerimaan CPNS melalui metode CAT}

Berdasarkan hasil analisis data pada setiap dimensi dari transparansi yaitu keterbukaan, ketersediaan, dan mudah dimengerti, secara umum diperoleh bahwa rata-rata opini peserta berada pada kategori baik. Berdasarkan pembahasan pada setiap dimensi dari transparansi yaitu keterbukaan, ketersediaan, dan mudah dimengerti, secara umum diperoleh bahwa rata-rata opini peserta berada pada kategori baik dan sangat baik untuk setiap tahapan seleksi penerimaan CPNS melalui metode CAT. Penggunaan metode CAT untuk seleksi penerimaan CPNS dapat meningkatkan opini, yang tadinya publik beropini negatif terhadap pelaksanaan seleksi penerimaan CPNS namun kini dengan adanya metode CAT terbentuk opini yang positif bagi publik.

Hal ini sejalan dengan asumsi teori deterministik teknologi yang disampaikan oleh McLuhan yang mengatakan bahwa " kita belajar, merasa dan berpikir terhadap apa yang kita lakukan karena pesan yang diterima teknologi menyediakan untuk itu". Artinya teknologi komunikasi menyediakan pesan dan membentuk perilaku kita sendiri. Dengan pemanfaatan Computer Assisted Test (CAT) dalam seleksi penerimaan Calon Pegawai Negeri Sipil. Teknologi membentuk individu bagaimana cara berpikir, berprilaku dalam masyarakat dari teknologi tersebut akhirnya mengarahkan manusia untuk bergerak dari satu abad teknologi ke abad teknologi. 
Penerapan TIK pada organisasi pemerintah tentunya memiliki tujuan yang berbeda. Adapun yang menjadi tujuan dari adanya teknologi informasi menurut Sutarman (2009), yaitu untuk memecahkan masalah, membuka kreativitas, dan meningkatkan efektivitas dan efesiensi dalam melakukan pekerjaan. Metode pemanfatan TIK dalam metode CAT dinilai efektif dan efisien karena transparansi seleksi penerimaan CPNS bisa membentuk opini yang positif. Sehingga pemanfaatan TIK dalam hal ini dapat meningkatkan efisiensi, efektivitas, transparansi, dan akuntabilitas penyelenggaraan pemerintah.

Pada teori informasi atau teori matematis melihat komunikasi sebagai fenomena mekanistis, matematis, dan informatif: komunikasi sebagai transmisi pesan dan bagaimana transmitter menggunakan saluran dan media komunikasi. Titik perhatiannya terletak pada akurasi dan efisiensi proses. Dalam hal ini CAT memanfaatkan jaringan internet sebagai saluran dan media penyebaran informasinya. Dengan penggunaan alat bantu komputer diharapkan akurasinya lebih tinggi dan juga memberikan efisiensi baik dari biaya maupun waktu. Transparansi informasi sebagai tujuan pemanfaatan tekhnologi ini tercapai yang ditunjukkan dengan terbentuknya opini peserta yang baik terhadap transparansi seleksi penerimaan CPNS melalui metode CAT.

Keberadaan metode CAT yang digunakan pada seleksi penerimaan calon pegawai negeri sipil pada Badan Kepegawaian Daerah terbukti menimbulkan peningkatan kualitas yang mengubah opini peserta seleksi CPNS yang tadinya kebanyakan beropini negatif namun berubah menjadi positif.

Konsep yang dikembangkan oleh Shannon and Weaver menegaskan bahwa untuk memahami informasi, kita perlu berasumsi bahwa semua tujuan komunikasi adalah mengatasi ketidakpastian (uncertainty).

Teori yang dikembangkan Shannon dan Weaver menyederhanakan persoalan komunikasi ini dengan memakai pemikiran-pemikiran probabilitas (kemungkinan). Para peserta seleksi penerimaan CPNS membentuk opini yang positif terhadap metode CAT karena dengan keterbukaan, ketersediaan informasi dan mudah dimengerti sehingga bisa mengatasi ketidakpastian informasi yang terjadi.

Teori informasi Shannon juga menganggap bahwa informasi dapat dihitung jumlahnya, dan bahwa informasi bersumber atau bermula dari suatu kejadian. Jumlah informasi yang dapat dikaitkan, atau dihasilkan oleh sebuah keadaan atau kejadian merupakan tingkat pengurangan (reduksi) ketidakpastian, atau pilihan kemungkinan, yang dapat muncul dari keadaan atau kejadian tersebut. Dengan kata yang lebih sederhana, teori ini berasumsi bahwa kita memperoleh informasi jika kita memperoleh kepastian tentang suatu kejadian atau suatu hal tertentu.

Teori yang dikemukakan Shannon and weaver sejalan dengan penggunaan teknologi baru (new media) yaitu Computer Assisted Test dalam seleksi penerimaan CPNS, teknologi ini dianggap mampu mengurangi ketidakpastian informasi. Peserta memberi opini yang baik atas informasi yang diberikan oleh metode ini baik dari segi keterbukaan informasi, ketersediaannya dan informasinya mudah dimengerti sehingga mengidentifikasikan bahwa metode ini benar- benar mengusung konsep transparansi informasi.

Transparansi informasi adalah salah satu syarat penting untuk menciptakan Good Governance. Salah satu upaya untuk mewujudkan pelaksanaan Good Governance adalah reformasi birokrasi. Reformasi birokrasi dalam pengadaan 
sumber daya pegawai negeri sipil yang berkualitas dan handal dilakukan melalui seleksi yang ketat yaitu dengan menggunakan seleksi sistem komputer atau metode Computer Assisted Test.

Seleksi penerimaan calon pegawai negeri sipil pada Badan Kepegawaian Daerah Kabupaten Bengkayang pada tahun 2020 telah menggunakan metode baru yaitu metode Computer Assisted Test (CAT). Metode CAT adalah suatu metode ujian dengan alat bantu komputer yang digunakan untuk mendapat standar minimal kompetensi dasar maupun standar kompetensi kepegawaian. Tujuan CAT itu adalah mempercepat proses pemeriksaan dan laporan hasil ujian, menciptakan menstandarisasi hasil ujian nasional, menetapkan standar nilai, dan meningkatkan transparansi, obyektivitas, akuntabilitas, dan efisiensi.

Menurut L.P Sinambela, (2016:6), salah satu tujuan pelayanan publik pada dasarnya adalah memuaskan masyarakat. Untuk mencapai kepuasan itu dituntut kualitas pelayanan prima dari beberapa unsur yang salah satu unsur adalah transparansi. Transparansi yaitu pelayanan yang bersifat terbuka, mudah dan dapat diakses oleh semua pihak yang membutuhkan dan disediakan secara memadai dan mudah mengerti (Ratminto dan Winarsih, 2015).

Transparansi sebagai salah satu unsur dari kualitas pelayanan prima juga menjadi salah satu tujuan CAT. Untuk itu perlu mengusung konsep transparansi dalam seleksi penerimaan calon pegawai negeri sipil melalui metode CAT. Dengan mengusung konsep transparansi dalam sistem ini diharapkan tercipta opini publik yang positif selaku peserta seleksi. Namun opini publik itu tergantung stimulus yang diterima.

Dari hasil penelitian ini, diperoleh opini yang positif terhadap transparansi seleksi penerimaan CPNS melalui metode CAT karena informasi seleksi penerimaan
CPNS melalui metode CAT terbuka, mudah dan dapat diakses oleh semua pihak yang membutuhkan serta tersedia secara memadai dan mudah dimengerti. Hal ini sesuai denga konsep transparansi yang dikemukakan Ratminto dan Winarsih (2015). Dengan terpenuhinya konsep transparansi sebagai perwujudan kualitas pelayanan prima maka tujuan pelayanan publik tercapai yaitu memuaskan masyarakat dengan begitu seleksi penerimaan CPNS melalui metode Computer Assisted Test bisa memuaskan masyarakat pada umumnya dan peserta pada khususnya.

Hal ini menunjukkan opini yang positif terhadap transparansi seleksi penerimaan CPNS karena informasi seleksi penerimaan CPNS melalui metode CAT terbuka, mudah dan dapat diakses oleh semua pihak yang membutuhkan serta tersedia secara memadai dan mudah dimengerti. Hal ini sesuai dengan konsep transparansi yang dikemukakan Ratminto dan Winarsih (2015), yakni transparansi yaitu pelayanan yang bersifat terbuka, mudah dan dapat diakses oleh semua pihak yang membutuhkan dan disediakan secara memadai dan mudah mengerti.

Penggunaan metode CAT untuk seleksi penerimaan CPNS sangatlah efektif, yang tadinya publik beropini negatif terhadap pelaksanaan seleksi penerimaan CPNS namun dengan adanya metode CAT terbentuk opini yang positif. Hal ini sejalan dengan asumsi teori deterministik teknologi yang disampaikan oleh McLuhan dalam Ermelinda (2013) yang mengatakan bahwa " kita belajar, merasa dan berpikir terhadap apa yang kita lakukan karena pesan yang diterima teknologi menyediakan untuk itu". Artinya teknologi komunikasi menyediakan pesan dan membentuk perilaku kita sendiri. Dengan pemanfaatan Computer Assisted Test (CAT) dalam seleksi penerimaan CPNS mengubah opini publik. Teknologi membentuk 
individu untuk berfikir cara yang lebih baik dan mengarahkan manusia untuk bergerak dari satu abad teknologi ke abad teknologi.

Penerapan TIK pada organisasi pemerintah tentunya memiliki tujuan yang berbeda. Adapun yang menjadi tujuan dari adanya teknologi informasi menurut Sutarman (2019), yaitu untuk memecahkan masalah, membuka kreativitas, dan meningkatkan efektivitas dan efesiensi dalam melakukan pekerjaan. Metode pemanfatan TIK dalam metode CAT dinilai efektif dan efisien karena transparansi seleksi penerimaan CPNS bisa membentuk opini yang positif. Sehingga pemanfaatan TIK dalam hal ini dapat meningkatkan efisiensi, efektivitas, transparansi, dan akuntabilitas penyelenggaraan pemerintah.

Proses pemanfaatan teknologi CAT dalam seleksi penerimaan CPNS dalam aplikasinya merupakan proses komunikasi secara detail yang sesuai dengan asumsi teori informasi yang dikemukaan oleh Shannon and Warren Weaver dalam Ermelinda (2013), dimana asumsi pada bagian pertama dari proses informasi adalah sumber informasi yang menciptakan pesan atau rangkaian pesan untuk dikomunikasikan. Pada tahap berikutnya pesan diubah dalam bentuk sinyal oleh transmister sehingga disalurkan kepada penerima. Penerima lalu menyusun kembali sinyal menjadi pesan sehingga mencapai tujuan.

Pada teori informasi atau teori matematis melihat komunikasi sebagai fenomena mekanistis, matematis, dan informatif. Titik perhatiannya terletak pada akurasi dan efisiensi proses. Dalam hal ini CAT memanfaatkan jaringan internet sebagai saluran dan media penyebaran informasinya. Dengan penggunaan alat bantu komputer diharapkan akurasinya lebih tinggi dan juga memberikan efisiensi baik dari biaya maupun waktu. Transparansi informasi sebagai tujuan pemanfaatan tekhnologi tercapai yang ditunjukkan dengan terbentuknya opini peserta yang baik terhadap transparansi seleksi penerimaan CPNS melelaui metode CAT. Sehingga keberadaan metode CAT yang digunakan pada seleksi penerimaan CPNS pada Badan Kepegawaian Daerah terbukti menimbulkan peningkatan kualitas yang mengubah opini peserta seleksi CPNS yang tadinya kebanyakan beropini negatif namun berubah menjadi positif.

Konsep yang dikembangkan oleh Shannon and Weaver menegaskan bahwa untuk memahami informasi, kita perlu berasumsi bahwa semua tujuan komunikasi adalah mengatasi ketidakpastian (uncertainty). Teori yang dikembangkan Shannon dan Weaver menyederhanakan persoalan komunikasi ini dengan memakai pemikiran-pemikiran probabilitas (kemungkinan). Para peserta seleksi penerimaan CPNS membentuk opini yang positif terhadap metode CAT karena dengan keterbukaan, ketersediaan informasi dan mudah dimengerti sehingga bisa mengatasi ketidakpastian informasi yang terjadi.

Teori yang dikemukakan Shannon and weaver sejalan dengan penggunaan teknologi baru (new media) yaitu Computer Assisted Test dalam seleksi penerimaan CPNS, teknologi ini dianggap mampu mengurangi ketidakpastian informasi. Peserta memberi opini yang baik atas informasi yang diberikan oleh metode ini baik dari segi keterbukaan informasi, ketersediaannya dan informasinya mudah dimengerti sehingga mengidentifikasikan bahwa metode ini benar- benar mengusung konsep transparansi informasi.

Transparansi informasi adalah salah satu syarat penting untuk menciptakan Good Governance. Salah satu upaya untuk mewujudkan pelaksanaan Good Governance adalah reformasi birokrasi. Reformasi birokrasi dalam pengadaan 
sumber daya pegawai negeri sipil yang berkualitas dan handal dilakukan melalui seleksi yang ketat yaitu dengan menggunakan seleksi sistem komputer atau metode Computer Assisted Test.

Seleksi penerimaan calon pegawai negeri sipil pada Badan Kepegawaian Daerah Provinsi Sulawesi Barat pada tahun 2013 telah menggunakan metode baru yaitu metode Computer Assisted Test (CAT). Metode CAT adalah suatu metode ujian dengan alat bantu komputer yang digunakan untuk mendapat standar minimal kompetensi dasar maupun standar kompetensi kepegawaian. Tujuan CAT itu adalah mempercepat proses pemeriksaan dan laporan hasil ujian, menciptakan menstandarisasi hasil ujian nasional, menetapkan standar nilai, dan meningkatkan transparansi, obyektivitas, akuntabilitas, dan efisiensi.

Menurut L.P Sinambela, (2016:6), salah satu tujuan pelayanan publik pada dasarnya adalah memuaskan masyarakat. Untuk mencapai kepuasan itu dituntut kualitas pelayanan prima dari beberapa unsur yang salah satu unsur adalah transparansi. Transparansi yaitu pelayanan yang bersifat terbuka, mudah dan dapat diakses oleh semua pihak yang membutuhkan dan disediakan secara memadai dan mudah mengerti (Ratminto dan Winarsih, 2015).

Transparansi sebagai salah satu unsur dari kualitas pelayanan prima juga menjadi salah satu tujuan CAT. Untuk itu perlu mengusung konsep transparansi dalam seleksi penerimaan calon pegawai negeri sipil melalui metode CAT. Dengan mengusung konsep transparansi dalam sistem ini diharapkan tercipta opini publik yang positif selaku peserta seleksi. Namun opini publik itu tergantung stimulus yang diterima.

Dari hasil penelitian ini, diperoleh opini yang positif terhadap transparansi seleksi penerimaan CPNS melalui metode CAT karena informasi seleksi penerimaan
CPNS melalui metode CAT terbuka, mudah dan dapat diakses oleh semua pihak yang membutuhkan serta tersedia secara memadai dan mudah dimengerti. Hal ini sesuai denga konsep transparansi yang dikemukakan Ratminto dan Winarsih (2015). Dengan terpenuhinya konsep transparansi sebagai perwujudan kualitas pelayanan prima maka tujuan pelayanan publik tercapai yaitu memuaskan masyarakat dengan begitu seleksi penerimaan CPNS melalui metode Computer Assisted Test bisa memuaskan masyarakat pada umumnya dan peserta pada khususnya.

\section{SIMPULAN}

Seleksi penerimaan CPNS melalui metode CAT pada Badan Kepegawaian Daerah Kabupaten Bengkayang membentuk opini yang positif karena ratarata opini peserta baik dan sangat baik yang berarti informasi seleksi penerimaan CPNS melalui metode CAT terbuka, mudah dan dapat diakses oleh semua pihak yang membutuhkan serta tersedia secara memadai dan mudah dimengerti. Sistem CAT yang memanfaatan teknologi informasi dan komunikasi (TIK) dalam seleksi penerimaan CPNS dinilai mampu meningkatkan efisiensi, efektivitas, transparansi, dan akuntabilitas penyelenggaraan pemerintah.

\section{REFERENSI}

Ermelinda GP. (2013). Pengaruh Pemanfaatan Sistem Informasi Elektronik Terhadap Kinerja Dosen Universitas Musamus Merauke. Tesis. Universitas Hasanuddin. Makassar.

https://finance.detik.com

https://nasional.tempo.co/read/510369/m

cw-catat-10-titik-rawan-kecuranganseleksi-cpns

https://www.tribunnews.com 
Ishak. (2018). Pengelolaan Perpustakaan Berbasis Teknologi Informasi. Pustaka: Jurnal Studi Perpustakaan dan Informasi, Vol. 4, No. 2 pp 87.

Jogiyanto. (2013). Analisis dan Desain Informasi, Andi Yogyakarta.

Kim Pan Suk. (2017). How to Build and Sustain Transparency and Accountability in Public Sector Yonsei University, Seoul. Jakarta: UNDESA bekerjasama dengan Kementerian PAN, UNGC, dan UNDP.

Krina Lalolo Loina P. (2013). Indikator Dan Alat Ukur Prinsip Akuntabilitas, Transparansi dan Partisipasi. Jakarta: Sekretariat Good Governance Badan Perencanaan Pembangunan Nasional.

Kriyantono Rachmat. (2012). Teknik Praktis Riset Komunikasi. Jakarta: Kencana Prenada Media Group.

Pusat Pengembangan Sistem Rekritmen PNS Badan Kepegawaian Negara. (2010). CAT Untuk Indonesia. Jakarta : Biro Humas dan Protokol BKN.

Rogers Everett M. (1986). Communication Technology. London: The Free Press, Coller Macmillan Publ.

Sinambela L.P. (2016). Reformasi Pelayanan Publik Teori, Kebijakan dan Implementasi. Jakarta : Raja Grafindo Persada.

Sutarman. (2019). Pengantar Teknologi Informasi. Jakarta: Sinar Grafika Offset.

Winarsih (2015). Manajemen Pelayanan Pengembangan Model Konseptual, Penerapan Citizen's Charter dan Standar Pelayanan Minimal Cetakan XII. Yogyakarta: Pustaka Pelajar.

www.menpan.go.id 